\title{
Model Purwarupa Pengukuran Kondisi Tubuh saat Olah Raga Aerobik dengan Metode Fuzzy Mamdani Model Purwarupa
}

\author{
Dodi Setiabudi ${ }^{1}$ dan Andina Maharani ${ }^{2}$ \\ ${ }^{1,2}$ Jurusan Teknik Elektro, Fakultas Teknik, Universitas Jember \\ Jl. Kalimantan No. 37, Jember 68121 \\ Email: dodi@unej.ac.id
}

\begin{abstract}
Abstrak-Penelitian ini bertujuan untuk mengembangkan ilmu kesehatan dan teknologi berupa alat pencegahan kelelahan yaitu mengukur kondisi tubuh berupa detak jantung dan laju napas manusia. Kemudian bisa mengambil keputusan berupa keadaan lanjut atau berhenti serta dapat dimonitor dari jarak jauh menggunakan radio telemetry. Diharapkan alat ini akan memberi manfaat bagi pengguna yang aktif berolahraga khususnya jenis aerobik. Alat pengukur kondisi tubuh ini menggunakan sensor detak jantung dan laju napas. Sensor laju napas terbuat dari sensor tekanan berbasis Arduino UNO. Sensor ini dapat digunakan untuk merancang alat pendeteksi kondisi tubuh saat berolahraga sehingga dapat mengetahui batas maksimum untuk mencegah kelelahan. Pengambilan keputusan menggunakan metode fuzzy logic. Kontrol output fuzzy yaitu kondisi lanjut ketika kondisi detak jantung pelan hingga berat dengan range antara 40 sampai 165 bpm dan kondisi laju napas lambat hingga normal dengan range 13 sampai 20 bpm, dianggap kondisi berhenti ketika kondisi detak jantung anaerob dengan range $>165$ bpm dan kondisi laju napas cepat dengan range $>\mathbf{2 0} \mathrm{bpm}$. Hasil pengujian sensor detak jantung memiliki error persen $=\mathbf{2 , 5 8} \%$. Uji sensor laju napas memiliki error persen $=\mathbf{5 , 0 8} \%$. Sistem pengujian output fuzzy yang dilakukan telah sesuai dengan rule base. Hasil pengukuran jarak maksimum pengiriman radio sejauh 140 meter tanpa penghalang dan 96 meter dengan penghalang.
\end{abstract}

Kata kunci: kelelahan, fuzzy logic, sensor detak jantung, sensor laju napas, Arduino UNO, radio telemetry.

\begin{abstract}
This project aims to develop the science of health and technology in the form of prevention of fatigue by measuring the condition of the body in the form of heart rate and human respiratory rate. Then can take the decision of a state of continued or stopped and can be monitored remotely using radio telemetry. It is expected that this tool will provide benefits for teens who are exercising, especially cycling. This body condition meter uses the heartbeat and breathing rate sensors. The breathing rate sensor is made of Arduino UNO-based pressure sensors. This sensor can be used to design the body condition detector while exercising so as to know the maximum limit to avoid fatigue. The decision making of the system is using fuzzy logic method. Fuzzy output controls are advanced conditions when the heart rate condition is slow to severe with a range of between 40 to 165 bpm and a normal slow breathing rate with a range of 13 to $20 \mathrm{bpm}$, considered to be a stop condition when anaerobic heart rate with range $>165 \mathrm{bpm}$ and rate conditions rapid breathing with range $>20 \mathrm{bpm}$. Heart rate sensor test results have an average percent error of 2,58\%. The results of the breath rate sensor tests have an average percent error of $5.08 \%$. The fuzzy output test results are in accordance with the rule base. Results of measuring the maximum distance of radio delivery are as far as 140 meters without a barrier and 96 meters with a barrier.
\end{abstract}

Keywords: kelelahan, fuzzy logic, heartbeat, breathing rate sensor, Arduino UNO, radio telemetry.

\section{PENDAHULUAN}

Jenis olahraga aerobik adalah jenis olahraga yang menggunakan energi dari hasil pembakaran oksigen, dilakukan secara sistematis dengan meningkatkan beban secara bertahap dan terus-menerus tanpa menimbulkan kelelahan. Olahraga aerobik bermacam-macam yaitu jalan, jogging, lari, bersepeda dan renang. Tubuh memiliki kemampuan untuk mengatur energi dalam menghadapi keadaan darurat yang mungkin timbul, hal ini disebut kebugaran fisik. Sehingga tubuh tetap dapat melakukan aktivitas dan berfungsi secara efektif. Selama melakukan olahraga aerobik ini perlu diperhatikan intensitas waktu latihan yang perlu direncanakan sebelumnya [1].

Kelelahan merupakan gejala serius yang harus didiagnosis, meskipun hal tersebut jarang terjadi selama dilakukannya olahraga. Sehingga perlunya pengembangan akan sebuah metode kesehatan tentang pelaksanaan olahraga yang tepat. Sistem deteksi secar dini akan memperkecil kemungkinan adanya latihan olahraga yang membahayakan [2].

Olahraga memiliki pengaruh yang sangat besar pada sistem sirkulasi dan pernapasan. Kedua hal tersebut selalu berjalan beriringan sebagai respon dari homeostasis yang dilakukan saat olahraga tingkat sedang hingga olahraga berat. Olahraga juga mempengaruhi turunnya tekanan darah sementara dibawah normal, hal ini mungkin disebabkan karena adanya penumpukan metabolit sehingga dalam periode singkat pembuluh otot tetap berdilatasi. Setelah beberapa saat tekanan darah akan kembali normal seperti sebelum olahraga, sedangkan untuk denyut jantung lebih lambat kembali normal [3]. 
Diagnosa hasil denyut jantung per menit sangat mempengaruhi kondisi fisik maupun mental seseorang. Hal ini dikarenakan perubahan kondisi fisik dan mental sulit diamati. Perubahan ini yang mengakibatkan perubahan frekuensi denyut jantung tiap menitnya. Kecepatan frekuensi jantung dipengaruhi oleh banyak hal misalnya seperti saat adanya peningkatan suhu, saat terjadinya olahraga misalnya maka akan melemahkan sistem metabolik di jantung. Perubahan suhu sangat mempengaruhi kinerja jantung, sehingga perlu dilakukan pengaturan suhu tubuh saat berolahraga [4].

Pada bidang kedokteran diperlukan adanya teknologi pemantauan kondisi pasien dari jarak jauh tanpa menggunakan kabel. Dari hasil pemantauan tersebut diharapakan adanya sistem yang dapat pemantau kondisi secara keseluruhan dan dapat menganalisanya tanpa harus melihat langsung [5]. Teknologi yang digunakan untuk pemantuan kondisi pasien menggunakan modul canggih yang dapat memantau pasien kelainan jantung dan gangguan fisik. Sensor yang digunakan pada pemantauan ini menggunakan sensor detak jantung dan sensor suhu. Sensor yang digunakan harus lebih akurat sehingga tidak diperlukan lagi pengukuran menggunakan alat ukur tradisional seperti termometer atau perangkat lainnya [6].

Tujuan dari penelitan ini adalah menghasilkan model purwarupa pengukuran detak jantung dan laju napas untuk pencegahan kelelahan sehingga dapat meminimalkan cedera yang diakibatkan dan dapat dipantau dari jarak jauh hasil pengukurannya.

\section{METODE}

\section{A. Perancangan Sistem}

Pada alat yang telah dibuat merupakan alat yang dapat mendeteksi kelelahan manusia berdasarkan dua tanda vital yang diukur. Untuk mengetahui kelelahan tersebut dilakukan pengukuran tanda vital berupa detak jantung dan laju napas manusia. Dari hasil pengukuran tanda vital tersebut maka dapat diketahui kondisi tubuh saat berolahraga aerobik untuk mencegah terjadinya kelelahan. Kondisi tubuh tersebut diolah dengan sebuah metode yaitu logika fuzzy. Logika fuzzy dapat menyimpulkan hasil pengukuran kondisi tubuh saat lelah. Dengan adanya logika fuzzy alat akan memberitahu untuk dapat melanjutkan olahraga atau harus berhenti.

Pada penelitian ini menggunakan rangkaian sensor detak jantung dan sensor laju napas, kedua sensor tersebut sebagai masukan ke mikrokontroler berupa Arduino UNO, kemudian keluaran dari mikrokontroler ditampilkan pada LCD dan data dikirim melalui frekuensi radio untuk dapat diterima dan dibaca di laptop maupun handphone (support $O T G)$.

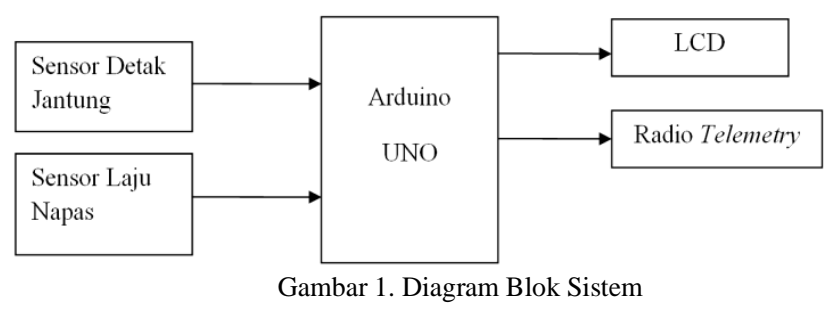

Prinsip kerja alat ini yaitu mengukur parameter dari detak jantung dan laju napas manusia dalam satu menit yang kemudian diproses oleh Arduino untuk menentukan kesimpulan kondisi tubuh menggunakan fuzzy. Hasil pengukuran parameter tersebut dan hasil kesimpulan ditampilkan pada LCD dan disimpan pada SD card, hasil pengukuran tersebut dapat dimonitor dari jarak jauh dengan menggunakan radio telemetry.

\section{B. Sensor Detak Jantung (Pulse Sensor)}

Sensor detak jantung pada gambar 2 merupakan sensor yang dapat membaca jumlah denyut pada jantung tiap menitnya dengan satuan BPM (beats per minute). Sensor detak jantung ini menggunakan pulse sensor yang telah mendukung Arduino dengan satuan BPM (beats per minute). Sensor ini merupakan sensor yang diletakkan di jari dengan membaca sinyal yang telah dikuatkan amplitudonya lalu kembali ke titik referensi [8].
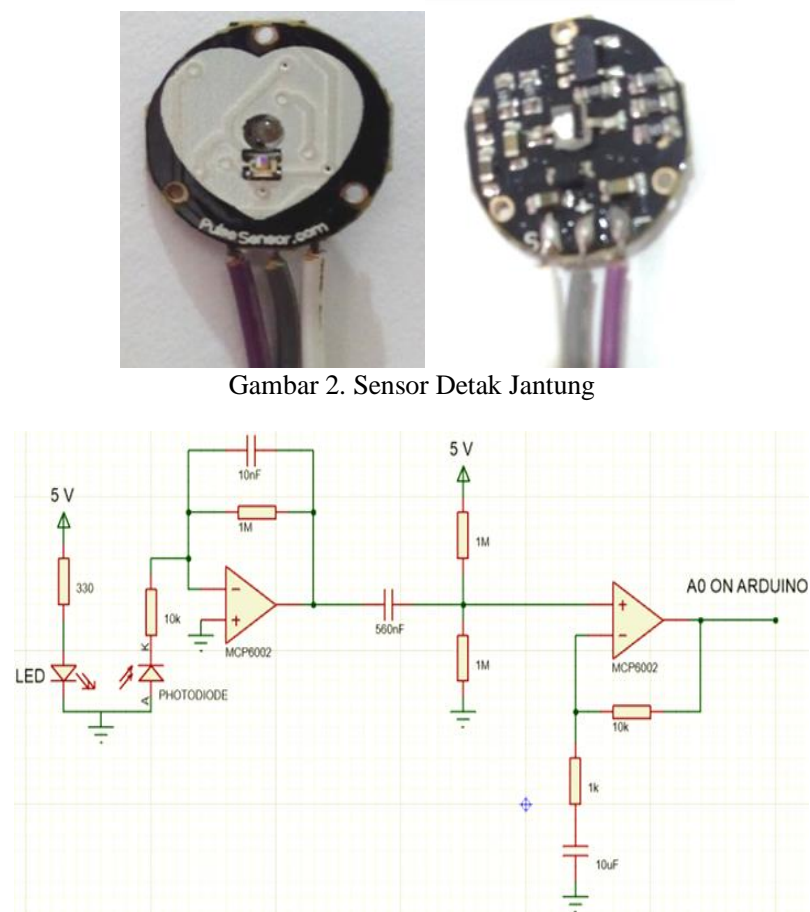

Gambar 3. Rangkaian Sensor Detak Jantung

Pada Gambar 3 merupakan rangkaian yang ada dibalik sensor detak jantung. Rangkaian tersebut merupakan kombinasi dari rangkaian finger cuff, transimpedance stage, high-pass filter, and AC gain-stage. Rangkaian finger cuff merupakan rangkaian input yaitu terdiri LED dan fotodioda yang membaca plasma darah pada permukaan kulit.

\section{Sensor Laju Napas (MPX2010DP)}

Sensor laju napas pada gambar 4 merupakan sensor yang dapat membaca jumlah respirasi pada paru-paru tiap menitnya dengan satuan BPM (breaths per minute). Sensor laju nafas ini dibuat menggunakan sensor tekanan tipe MPX2010DP dengan satuan berupa BPM (breath per minute). Sensor ini bekerja pada tegangan DC $5 \mathrm{~V}$ dengan arus $7 \mathrm{~mA}$. Data yang dikeluarkan berupa data analog. 
Sensor tekanan ini memiliki 2 input yaitu tekanan udara masuk dan tekanan udara keluar. Udara masuk menggunakan tekanan udara pada suntikan yang telah diatur tekanannya dan udara keluar merupakan tarikan napas yang diambil melalui masker oksigen yang diletakkan dihidung. Dimana perbedaan nilai dari udara masuk dan keluar tersebut akan menjadi nilai yang dihitung sebagai perhitungan adanya laju napas. Sehingga jika nilai udara keluar melebihi nilai batas udara masuk (324 dalam nilai ADC) maka dianggap ada laju napas dan nilai tersebut langsung dikonversikan dalam 1 menit [9].
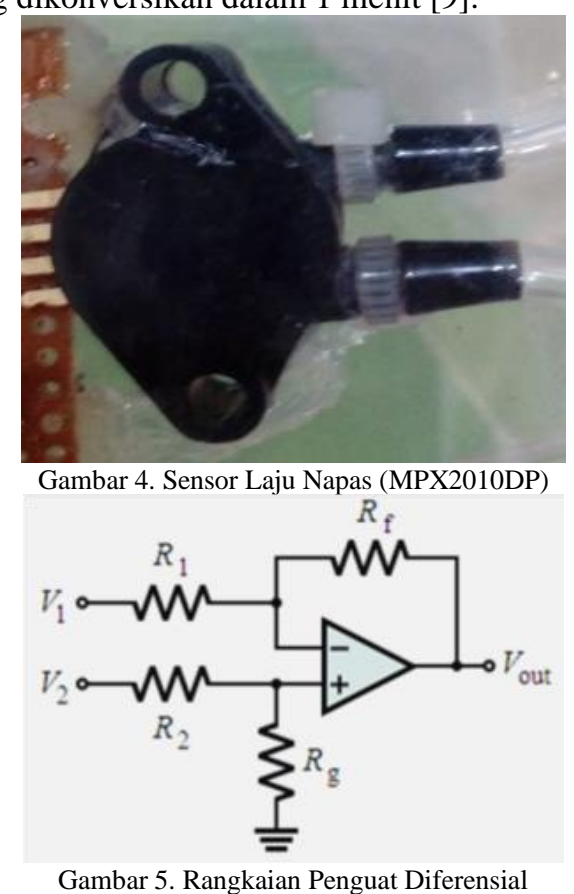

Fungsi adanya rangkaian penguat diferensial (gambar 5) pada sensor laju napas yang terbuat dari sensor tekanan yaitu mengkonversi variabel dinamik ke dalam sinyal elektrik. Rangkaian ini menggunakan rangkaian inverting.

\section{E. Perancangan Output Sistem Telemetry}

Hasil keluaran pada sistem akan ditampilkan di LCD dengan ukuran 16x2. Hasil pengukuran yang ditampilkan yaitu pada baris pertama terdapat hasil pengukuran laju napas yang disingkat menjadi $\mathrm{LN}$ dan hasil pengukuran detak jantung yang disingkat menjadi DJ. Pada baris kedua ada hasil kondisi dari output fuzzy berupa kondisi lanjut atau berhenti dan nilai pengaturan threshold dari sensor laju napas.

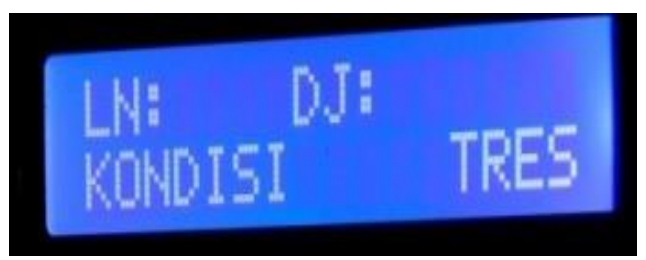

Gambar 6. Tampilan LCD

Selain tampilan pada LCD adapula hasil output yang dikirimkan melalui frekuensi radio (telemetry). Data yang dikirim secara telemetry yaitu pengukuran laju napas, detak jantung, dan output fuzzy saja. Hasil pengukuran ini ditampilkan pada komputer yang support dan ter-instal
Arduino karena radio yang digunakan juga radio yang support Arduino. Jika pada Arduino untuk menampilkan hasil output dengan cara ditampilkan pada serial monitor yang telah tersedia pada software tersebut. Untuk tampilan pada lainnya bisa ditampilkan pada smartphone yang telah support OTG. Pada smartphone diperlukan software serial USB terminal dengan kecepatan pengiriman data disesuaikan dengan program pada Arduino yaitu 57600 baudrate.Pada gambar 7 ditampilkan skema perancangan system telemetri.

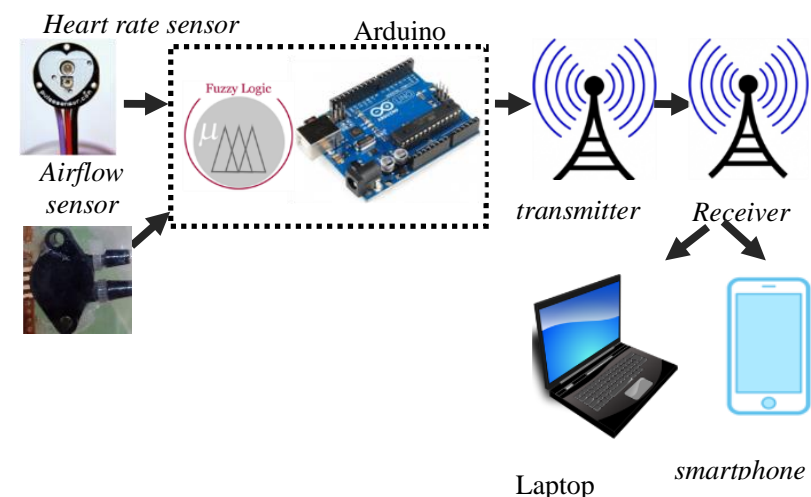

Gambar 7. Skema Perancangan Sistem Telemetry

F. Desain Kontrol Fuzzy

Fuzzyfikasi (fuzzification) merupakan proses penentuan nilai masukan derajat keanggotaan dari suatu variabel numerik non-fuzzy menjadi himpunan fuzzy [7]. Untuk mendesain fuzzy pengukuran kondisi tubuh saat olah raga aerobik diperlukan pemilihan parameter yang akan diuji. Pemilihan parameter ini telah dikonsultasikan dengan dokter yang ahli pada bidang fisiologi. Parameter yang terpilih sebagai input yaitu detak jantung dan laju napas manusia, sedangkan output yang dihasilkan berupa kondisi lanjut dan berhenti.

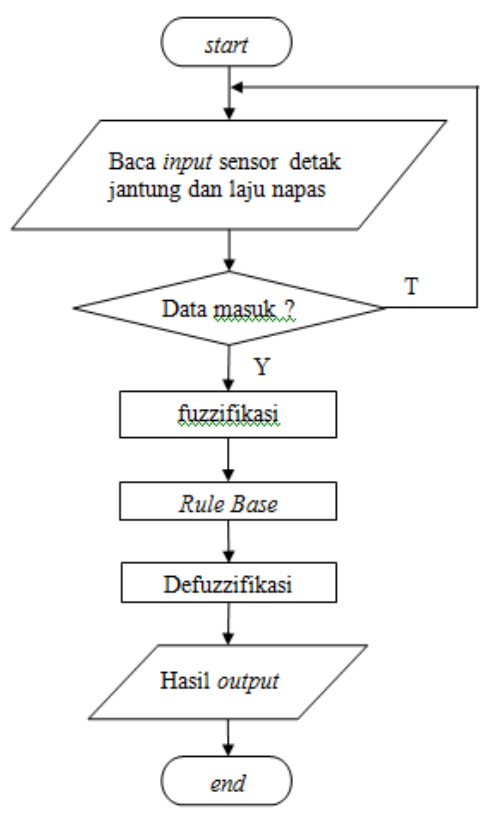

Gambar 8. Flowchart Fuzzy Logic

Proses fuzzifikasi yaitu mengumpulkan informasi data detak jantung dan laju napas. Dari data tersebut kemudian dikategorikan menjadi masing-masing himpunan. Untuk 
detak jantung terdapat 5 himpunan dan fungsi keanggotaan berupa pelan, normal, aktivitas ringan, aktivitas berat, dan anaerob, sedangkan untuk laju napas terdapat 3 himpunan dan fungsi keanggotaan berupa lambat, normal, dan cepat. Kedua proses pembuatan rule base yaitu menentukan aturan-aturan untuk himpunan yang telah didesain seperti dijelaskan pada gambar 8. Dari 5 himpunan detak jantung dan 3 himpunan laju napas maka didapatkan 15 aturan untuk dua kondisi yaitu berhenti atau lanjut. Terakhir proses defuzzifikasi yaitu jika sensor mendeteksi suatu nilai maka nilai tersebut akan langsung dihitung derajat keanggotaannya untuk dikonversikan ke dalam suatu himpunan yang telah dibuat. Proses ini merupakan proses realisasi dari fuzzifikasi.

Dari nilai himpunan yang dihasilkan dari detak jantung dan laju napas dapat ditentukan aturan yang sesuai untuk kondisi tersebut. Tabel 1 menujukkan hasil desain yang telah dibuat dan dikonsultasikan dengan pakar :

Tabel 1. Parameter Sensor Detak Jantung

\begin{tabular}{|c|c|}
\hline Parameter & Beat Per Minute (BPM) \\
\hline Pelan & $<70$ \\
\hline Normal & $65-105$ \\
\hline Aktivitas Ringan & $100-140$ \\
\hline Aktivitas Berat & $130-170$ \\
\hline Anaerob & $>165$ \\
\hline
\end{tabular}

Dari parameter pada Tabel 1 dapat direpresentasikan dalam sebuah grafik input fuzzy untuk menentukan titik detak jantung yang sesuai. Pada Gambar 9 variabel suhu tubuh didefinisikan lima himpunan fuzzy, yaitu, PELAN, NORMAL, AKTIVITAS RINGAN, AKTIVITAS BERAT dan ANAEROB. Dari parameter tersebut dapat direpresentasikan dalam sebuah grafik input fuzzy.

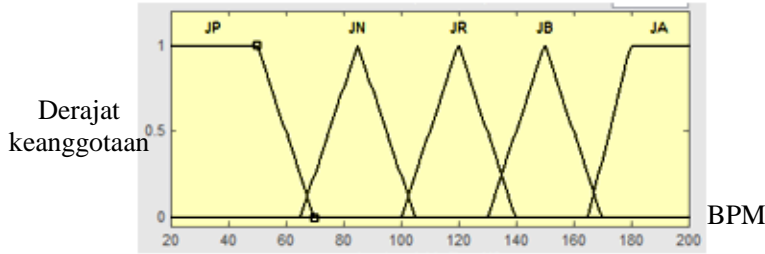

Gambar 9. Representasi Variabel Himpunan Fuzzy Detak Jantung

Pada himpunan fuzzy lima variabel dari himpunan detak jantung, variabel JP (Jantung Pelan) merupakan fungsi keanggotaan dari himpunan detak jantung pelan. Variabel JN (Jantung Normal) merupakan fungsi keanggotaan dari himpunan detak jantung normal. Variabel JR (Jantung Ringan) merupakan fungsi keanggotaan dari himpunan detak jantung aktivitas ringan. Variabel JB (Jantung Berat) merupakan fungsi keanggotaan dari himpunan detak jantung aktivitas berat. Variabel JA (Jantung Anaerob) merupakan fungsi keanggotaan dari himpunan detak jantung anaerob. Adapun sumbu vertikal merupakan derajat keanggotaan dari nilai input variabel detak jantung. Berikut sumbu keanggotaan dari variabel detak jantung:

$$
\text { upelan }=\left\{\begin{array}{c}
1 ; \mathrm{z} 1 \leq 50 \\
\frac{50-\mathrm{z} 1}{20} ; 50 \leq \mathrm{z} 1 \leq 70 \\
0 ; \mathrm{z} 1 \geq 70
\end{array}\right.
$$

$$
\begin{aligned}
& \mu \text { normal }=\left\{\begin{array}{c}
0 ; \mathrm{z} 1 \leq 65 \\
\frac{\mathrm{z} 1-65}{20} ; 65 \leq \mathrm{z} 1 \leq 85 \\
\frac{105-\mathrm{z} 1}{20} ; 85 \leq \mathrm{z} 1 \leq 105
\end{array}\right.
\end{aligned}
$$

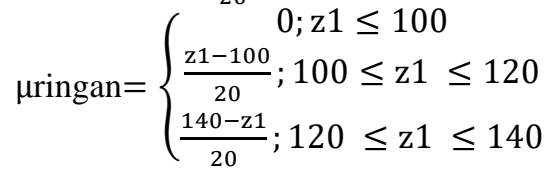

$$
\begin{aligned}
& \mu \text { berat }=\left\{\begin{array}{c}
0 ; \mathrm{z} 1 \leq 130 \\
\frac{\mathrm{z} 1-130}{20} ; 130 \leq \mathrm{z} 1 \leq 150 \\
\frac{170-\mathrm{z} 1}{20} ; 150 \leq \mathrm{z} 1 \leq 170
\end{array}\right.
\end{aligned}
$$

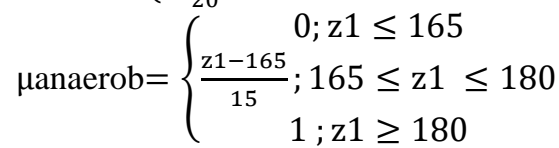

keterangan $: \mathrm{z} 1$ = hasil pengukuran detak jantung

Tabel 2. Parameter Laju Napas

\begin{tabular}{|c|c|}
\hline Parameter & Laju Napas \\
\hline Lambat & $<17$ \\
\hline Normal & $13-20$ \\
\hline Cepat & $>17$ \\
\hline
\end{tabular}

Dari parameter pada Tabel 2 dapat direpresentasikan dalam sebuah grafik input fuzzy untuk menentukan laju napas yang sesuai. Pada Gambar 10 variabel laju napas didefinisikan tiga himpunan fuzzy, yaitu lambat, normal dan cepat.

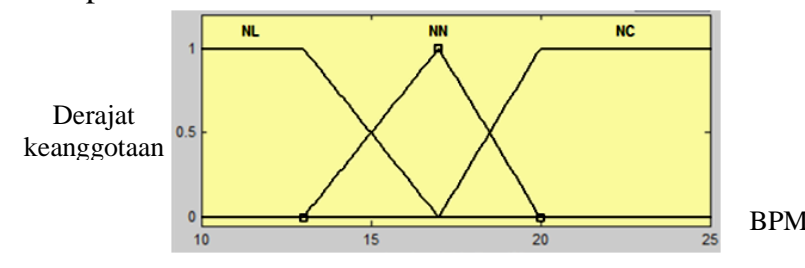

Gambar 10.Representasi Variabel Himpunan Fuzzy Laju Napas

Pada himpunan fuzzy laju napas, variabel NL (Nafas Lambat) merupakan fungsi keanggotaan dari himpunan laju napas lambat. Variabel NN (Nafas Normal) merupakan fungsi keanggotaan dari himpunan laju napas normal. Variabel NC (Nafas Cepat) merupakan fungsi keanggotaan dari himpunan laju napas cepat. Adapun sumbu vertikal merupakan derajat keanggotaan dari nilai input variabel laju napas. Berikut sumbu keanggotaan dari variabel laju napas:

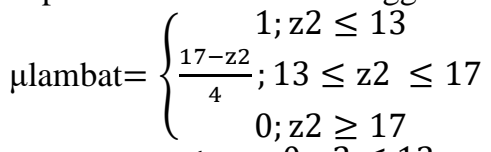

$$
\begin{aligned}
& \mu \text { normal }=\left\{\begin{array}{c}
0 ; \mathrm{z} 2 \leq 13 \\
\frac{\mathrm{z} 2-13}{4} ; 13 \leq \mathrm{z} 2 \leq 17 \\
\frac{20-\mathrm{z} 2}{3} ; 17 \leq \mathrm{z} 2 \leq 20
\end{array}\right. \\
& \mu c e p a t=\left\{\begin{array}{c}
0 ; \mathrm{z} 2 \leq 17 \\
\frac{\mathrm{z} 2-17}{3} ; 17 \leq \mathrm{z} 2 \leq 20 \\
1 ; \mathrm{z} 2 \geq 20
\end{array}\right.
\end{aligned}
$$

keterangan : $\mathrm{z} 2=$ hasil pengukuran laju napas

Kontrol fuzzy output, merupakan hasil keputusan dari rules yang telah dibuat yang berdasarkan nilai detak jantung dan laju napas. Output tersebut akan dipengaruhi oleh dua input yang telah ditentukan dan dapat berubah- 
ubah berdasarkan nilai ADC yang dikeluarkan oleh dua sensor.

\begin{tabular}{|c|c|} 
Tabel 3. Output Fuzzy Set \\
\hline Parameter & Nilai \\
\hline Berhenti & $0-50$ \\
\hline Lanjut & $0-50$ \\
\hline
\end{tabular}

Dari parameter pada Tabel 6 dapat direpresentasikan dalam sebuah grafik output fuzzy untuk menentukan keluaran yang sesuai. Pada Gambar 20 variabel output didefinisikan dua himpunan fuzzy, yaitu BERHENTI, dan LANJUT.

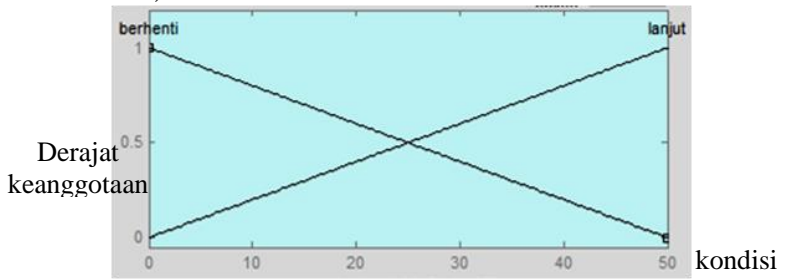

Gambar 11. Representasi Variabel Himpunan Output Fuzzy

Adapun sumbu vertikal merupakan tingkat keanggotaan dari nilai input variabel detak jantung dan laju napas. Berikut sumbu keanggotaan dari variabel berhenti dan lanjut:

$$
\begin{aligned}
& \mu \text { berhenti }=\left\{\begin{array}{c}
0 ; z 3 \geq 50 \\
\frac{50-\mathrm{zz} 3}{50} ; 0 \leq \mathrm{z} 3 \leq 50 \\
0 ; \mathrm{z} 3 \leq 0
\end{array}\right. \\
& \text { planjut }=\left\{\begin{array}{c}
0 ; \mathrm{z} 3 \leq 0 \\
\frac{\mathrm{z} 3-0}{50} ; 0 \leq \mathrm{z} 3 \leq 50
\end{array}\right.
\end{aligned}
$$$$
\text { keterangan : z3 }=\text { hasil kondisi dari output fuzzy }
$$

Dari beberapa data input yang didapat, maka dibuat suatu aturan atau rule yang akan menghasilkan keputusan dari fuzzy controller. Keputusan ini nantinya yang akan berperan sebagai output. Dasarnya rule ini adalah sebuah rule if - and - then yang mudah dimengerti karena hanya merupakan kata-kata terdapat 15 rule yang menghasilkan output yang menunjukkan hubungan antara detak jantung dan laju napas yang akan menghasilkan output berupa kondisi tubuh yaitu dapat lanjut atau harus berhenti.

\begin{tabular}{|c|c|c|c|c|c|}
\hline $\begin{array}{c}\text { Detak Jantung } \\
\text { Laju Napas }\end{array}$ & Pelan & Normal & Ringan & Berat & Anaerob \\
\hline Lambat & Lanjut & Lanjut & Lanjut & Lanjut & Berhenti \\
\hline Normal & Lanjut & Lanjut & Lanjut & Lanjut & Berhenti \\
\hline Cepat & Berhenti & Berhenti & Berhenti & Berhenti & Berhenti \\
\hline
\end{tabular}

\section{G. Implementasi Perangkat Keras}

Seperti yang telah dijelaskan sebelumnya alat yang telah dibuat menggunakan sensor detak jantung dan laju napas (gambar 12 dan 13). Untuk mikrokontrolernya menggunakan Arduino Uno. Sistem yang telah dibuat dapat menampilkan hasil pengukuran kondisi detak jantung dan laju napas. Pemilihan dua parameter tersebut untuk dapat mencegah terjadinya kelelahan saat berolahraga. Dari hasil pengukuran juga dapat langsung diambil kesimpulan berupa kondisi berhenti atau lanjut menggunakan logika fuzzy. Berikut hasil alat yang telah dibuat:
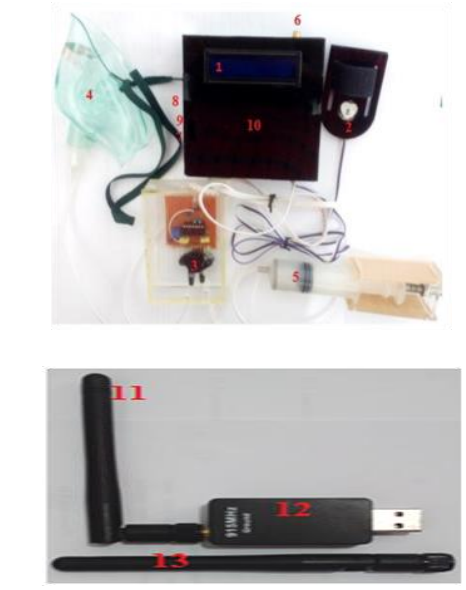

Gambar 13. Antena Radio dan USB Receiver

\section{H. Implementasi Fuzzy (Mamdani) pada Sistem}

Pada sistem logika fuzzy berfungsi sebagai pengambil keputusan akhir yaitu kondisi lanjut atau berhenti. Seperti yang telah dijelaskan pada penjelasan perancangan fuzzy. Hasil implementasi dari alat pencegah kelelahan ini dapat dilihat pada Gambar 14 dan 15 yaitu nilai input dari detak jantung dan laju nafas mempengaruhi keputusan yang akan ditentukan. Inputl merupakan himpunan detak jantung, input 2 merupakan himpunan laju nafas, dan output 1 merupakan himpunan dari kondisi lanjut dan berhenti.

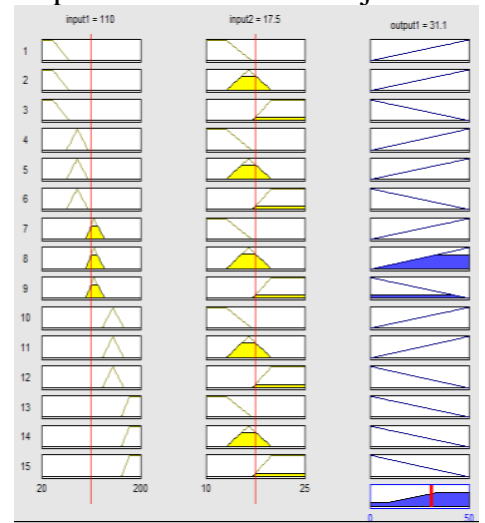

Gambar 14. Sampling Pengambilan Keputusan Lanjut

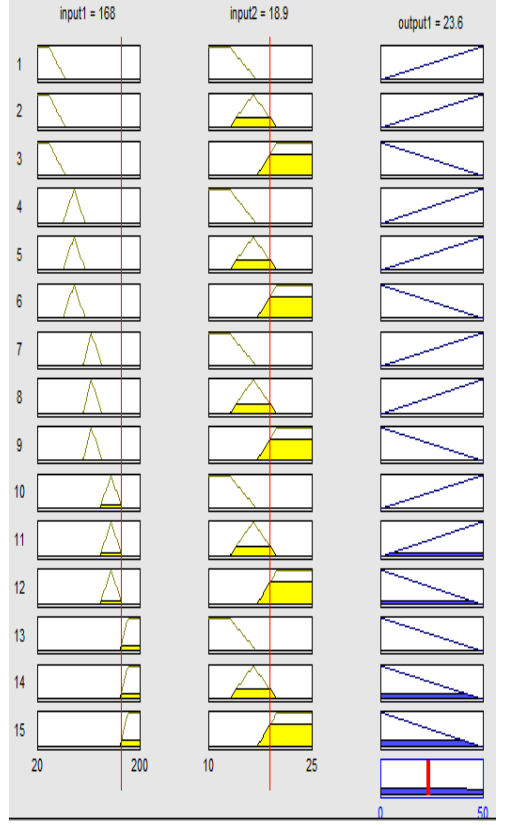


Gambar 15. Sampling Pengambilan Keputusan Berhenti

Pengambilan keputusan pada fuzzy Mamdani ini menggunakan metode COA (Center of Area) atau min-max yaitu saat implikasi mengambil nilai derajat keanggotaan terkecil $(\mathrm{min})$ dan saat agregasi mengambil nilai terbesar (max). Sedangkan untuk menentukan hasil akhirnya dengan menghitung titik tengah area (Center of Area) untuk menentukan output. Konstanta COA merupakan acuan dasar dalam menentukan area setiap keputusan yang telah ditentukan.

\section{Flowchart}

Pada sistem kontrol logika fuzzy menggunakan detak jantung dan laju napas yang pertama kali dilakukan adalah pengambilan data pada setiap sensor (input), yaitu sensor detak jantung dan laju napas yang akan diproses oleh Arduino. Setelah mendapatkan data input pada setiap sensor yang digunakan maka Arduino akan memproses data dengan menggunakan metode logika fuzzy. Output didapatkan dari rule base yang telah ditentukan kemudian ditampilkan pada LCD dan dikirim melalui frekuensi radio untuk dapat dimonitor langsung melalui laptop maupun handphone (support OTG).

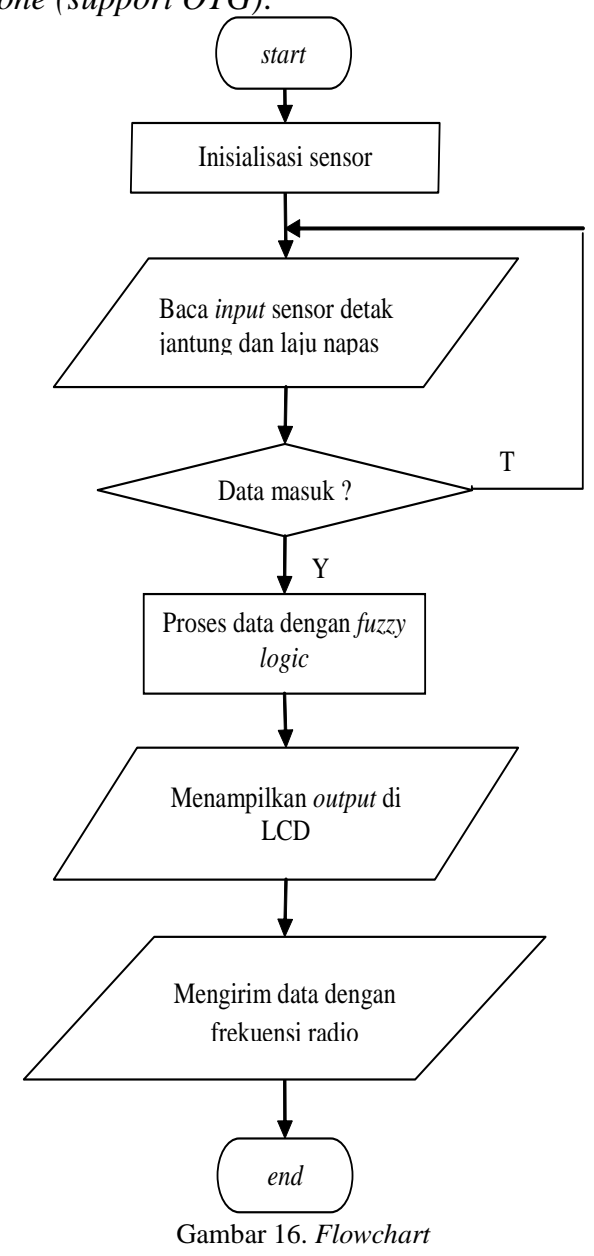

\section{HASIL DAN PEMBAHASAN}

Pada penelitian ini terdapat kalibrasi dan pengujian sensor, pengujian metode fuzzy mamdani dan pengujian system telemetri. Satuan dari sensor detak jantung menggunakan pulse sensor berupa BPM (beat per minute) dengan nilai detak jantung dari 1 hingga 200 dan satuan dari sensor laju napas menggunakan MPX2010DP berupa BPM (breath per minute) dengan nilai napas dari 1 hingga 30.

A. Kalibrasi Sensor Detak Jantung

Sebelum melakukan pengujian sensor detak jatung maka data diambil untuk dikalibrasi. Hal ini dilakukan untuk mengetahui perbandingan nilai pengukuran sensor dengan nilai hasil pengukuran alat ukur standar. Hasil pengukuran setelah kalibrasi ditunjukkan pada gambar 17. Berikut hasil kalibrasi yang telah dilakukan.

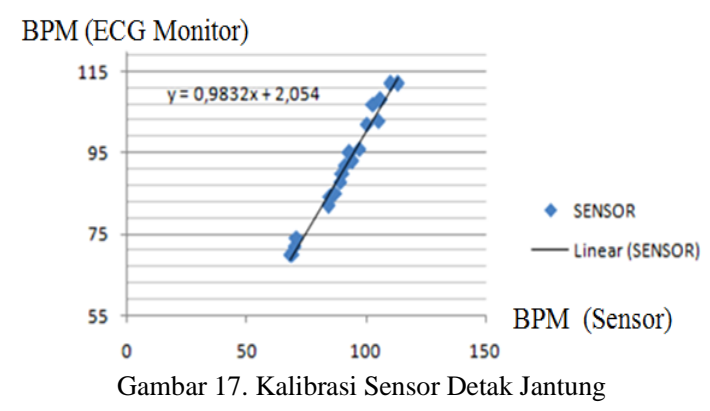

\section{B. Pengujian Sensor Detak Jantung}

Sensor ini merupakan sensor analog, konversi nilai analog ke digital menggunakan pembacaan sinyal yang dihasilkan oleh sensor dengan tinggi maksimum 512 dalam nilai ADC untuk pembacaan satu detak jantung. Kemudian dikonversikan ke dalam satu menit setelah data diambil selama satu detik. Untuk pengujian sensor ini dilakukan bersamaan dengan pengujian alat ukur detak jantung yaitu ECG monitor untuk menguji tingkat kesalahan data yang diperoleh oleh sensor tersebut. Langkah-langkah pengambilan data yaitu pertama menyambungkan dengan sumber tegangan DC 9V pada Arduino. Kedua memasang sensor pada ujung jari kemudian memasang ECG monitor pada ujung jari lainnya dan adapula elektroda yang terpasang di dada. Setelah terpasang data dapat diamati untuk dianalisa hasil masing-masing pengukurannya. Data diamati melalui LCD dan ECG diamati melalui layar alat tersebut. Berikut data hasil pengujian sensor detak jantung pada Tabel 9.

\begin{tabular}{|c|c|c|c|}
\hline No & $\begin{array}{c}\text { ECG } \\
\text { Monitor } \\
(\text { BPM })\end{array}$ & $\begin{array}{c}\text { Detak Jantung } \\
\text { Sensor } \\
(\text { BPM })\end{array}$ & Error $(\%)$ \\
\hline 1 & 85 & 86 & 1,17 \\
\hline 2 & 92 & 90 & 2,17 \\
\hline 3 & 100 & 98 & 2 \\
\hline 4 & 108 & 110 & 1,85 \\
\hline 5 & 103 & 101 & 1,94 \\
\hline 6 & 88 & 90 & 2,27 \\
\hline 7 & 95 & 92 & 3,15 \\
\hline 8 & 105 & 108 & 2,85 \\
\hline 9 & 107 & 110 & 2,80 \\
\hline 10 & 114 & 110 & 3,5 \\
\hline 11 & 84 & 89 & 5,95 \\
\hline 12 & 86 & 90 & 4,65 \\
\hline 13 & 90 & 92 & 2,22 \\
\hline 14 & 91 & 92 & 1,09 \\
\hline 15 & 94 & 93 & 1,06 \\
\hline 16 & & Rata-rata E\% & 2,58 \\
\hline
\end{tabular}


C. Kalibrasi Sensor Laju Napas

Sebelum melakukan pengujian sensor laju napas maka data diambil untuk dikalibrasi. Hal ini dilakukan untuk mengetahui perbandingan nilai pengukuran sensor dengan nilai hasil pengukuran alat ukur standar. Hasil pengukuran kalibrasi sensor laju napas ditunjukkan pada gambar 18 . Berikut hasil kalibrasi yang telah dilakukan.

\section{BPM (ECG Monitor)}

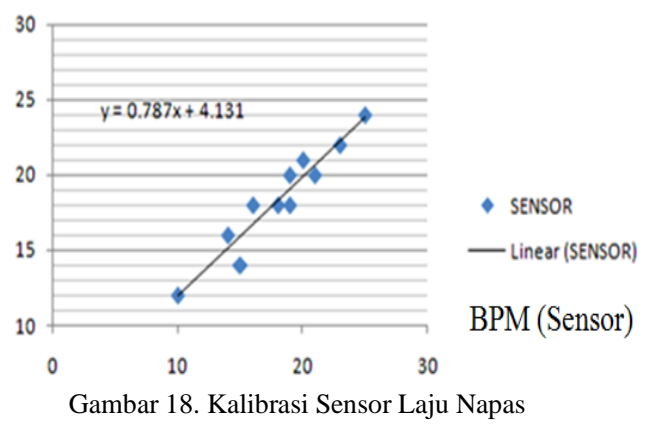

\section{Pengujian Sensor Laju Napas}

Sensor ini merupakan sensor analog, konversi nilai analog ke digital menggunakan pembacaan sinyal yang dihasilkan oleh sensor dengan tinggi maksimum 326 dalam nilai ADC untuk pembacaan satu laju napas. Kemudian dikonversikan ke dalam satu menit setelah data diambil selama satu detik. Untuk pengujian sensor laju napas dilakukan bersamaan dengan pengukuran menggunakan ECG monitor yang dapat mengukur detak jantung juga tingkat respirasi dan kadar oksigen secara bersamaan. Langkah-langkah pengambilan data yaitu pertama menyambungkan dengan sumber tegangan DC 9V pada Arduino. Kedua memasang masker oksigen pada hidung kemudian mengatur tekanan masukan pada sensor. Lalu mengatur nilai threshold sebesar 324 yang tampil pada LCD. Setelah terpasang dan semua telah siap maka data dapat diamati untuk dianalisa hasil masing-masing pengukurannya. Data diamati melalui LCD dan ECG diamati melalui layar alat tersebut. Berikut data hasil pengujian sensor laju napas pada Tabel 11 .

\begin{tabular}{|c|c|c|c|}
\hline No & $\begin{array}{c}\text { ECG Monitor } \\
(\text { BPM })\end{array}$ & $\begin{array}{c}\text { Sensor Laju } \\
\text { Napas (BPM) }\end{array}$ & Error (\%) \\
\hline 1 & 17 & 16 & 5,88 \\
\hline 2 & 26 & 27 & 3,84 \\
\hline 3 & 17 & 16 & 5,88 \\
\hline 4 & 21 & 20 & 4,76 \\
\hline 5 & 16 & 17 & 6,25 \\
\hline 6 & 25 & 23 & 8 \\
\hline 7 & 21 & 20 & 4,76 \\
\hline 8 & 20 & 20 & 0 \\
\hline 9 & 26 & 24 & 7,69 \\
\hline 10 & 25 & 23 & 8 \\
\hline 11 & 20 & 21 & 5 \\
\hline 12 & 24 & 25 & 4,16 \\
\hline 13 & 25 & 25 & 0 \\
\hline 14 & 25 & 26 & 4 \\
\hline 15 & 25 & 23 & 8 \\
\hline 16 & \multicolumn{2}{|c|}{ Rata-rata E\% } & 5,08 \\
\hline
\end{tabular}

\section{E. Pengujian Jarak Radio}

Pada pengujian ini menggunakan modul radio telemetry kit tipe 3DR V2 $915 \mathrm{MHz}$ yang telah mendukung Arduino. Radio ini dapat bekerja pada tegangan 5 Volt dan arus hingga $25 \mathrm{~mA}$ dan $100 \mathrm{~mA}$ untuk pemancar. Langkahlangkah pengujian jarak pengiriman data ini pertama semua antena harus terpasang (transmitter dan receiver). Kedua menyambungkan modul receiver pada perangkat yang akan menerima data (komputer atau ponsel pintar yang mendukung OTG). Setelah semua telah terpasang dengan benar lalu alat disambungkan dengan sumber tegangan DC 9V (kebutuhan Arduino). Data akan terkirim dan dapat di monitor melalui jarak jauh tanpa kabel (telemetry). Untuk monitor menggunakan laptop harus memiliki software IDE Arduino karena data ditampilkan pada serial monitor pada software tersebut dan untuk monitor menggunakan ponsel Android harus memiliki software serial USB terminal yang dapat di unduh dari play store. Tetapi untuk monitor dengan ponsel maka ponsel tersebut harus mendukung komunikasi dengan kabel OTG. Berikut hasil pengukuran pengiriman maksimum dari radio telemetry.

Pengujian jarak ini untuk mengetahui batas maksimum pengiriman data. Pengujian jarak ini dilakukan dua kali yaitu pertama pengukuran jarak maksimum dengan penghalang yaitu dibatasi oleh gedung atau tembok dan kedua pengukuran jarak maksimum dengan tanpa penghalang yaitu di luar ruangan. Kecepatan pengiriman data mengikuti sesuai dengan kecepatan pengiriman data pada pembacaan di Arduino yaitu 57600 baudrate.

\begin{tabular}{|c|c|c|}
\hline No & Jarak (meter) & Status \\
\hline 1 & 10 & Terkirim \\
\hline 2 & 20 & Terkirim \\
\hline 3 & 30 & Terkirim \\
\hline 4 & 40 & Terkirim \\
\hline 5 & 50 & Terkirim \\
\hline 6 & 60 & Terkirim \\
\hline 7 & 70 & Terkirim \\
\hline 8 & 80 & Terkirim \\
\hline 9 & 90 & Terkirim \\
\hline 10 & 100 & Terkirim \\
\hline 11 & 140 & Putus-putus \\
\hline 12 & $>140$ & Gagal \\
\hline
\end{tabular}

Tabel 13 Pengujian Jarak Radio dengan Penghalang

\begin{tabular}{|c|c|c|}
\hline No & Jarak (meter) & Status \\
\hline 1 & 10 & Terkirim \\
\hline 2 & 20 & Terkirim \\
\hline 3 & 30 & Terkirim \\
\hline 4 & 40 & Terkirim \\
\hline 5 & 50 & Terkirim \\
\hline 6 & 60 & Terkirim \\
\hline 7 & 70 & Terkirim \\
\hline 8 & 80 & Terkirim \\
\hline 9 & 90 & Terkirim \\
\hline 10 & 96 & Putus-putus \\
\hline 11 & $>96$ & Gagal \\
\hline
\end{tabular}

Dari hasil pengukuran tersebut maka dapat disimpulkan bahwa radio telemetry $915 \mathrm{MHz}$ yang digunakan memiliki batas maksimum jarak pengiriman data tanpa penghalang 
atau diluar ruangan sepanjang 140 meter dan dengan penghalang atau dibatasi oleh gedung atau tembok sepanjang 96 meter. Selisih jarak antara pengiriman tanpa penghalang dan dengan penghalang yaitu 44 meter.

\section{F. Pengujian Parameter Saat Menggunakan Radio}

Selama pengujian pengukuran jarak pengiriman data menggunakan radio didapatkan pula hasil pengukuran parameter dari detak jantung dan laju napas. Pengukuran parameter dilakukan dalam kondisi normal dan beraktifitas ringan. Berikut pada gambar 19 dan 20 hasil representasi pengukuran detak jantung dan laju napas.

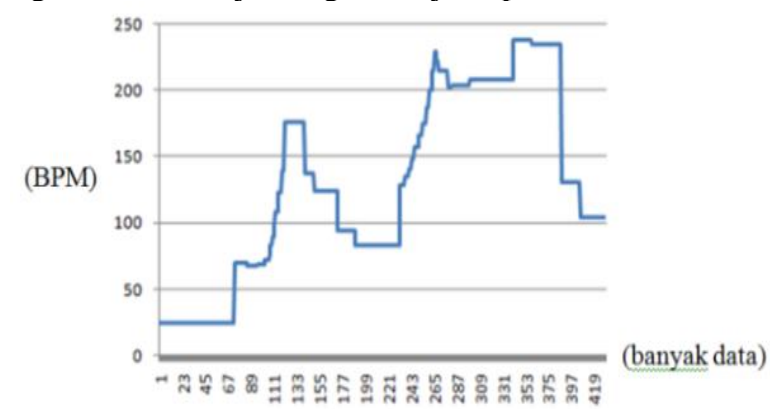

Gambar 19. Pengukuran Parameter Detak Jantung Saat Pengiriman Radio

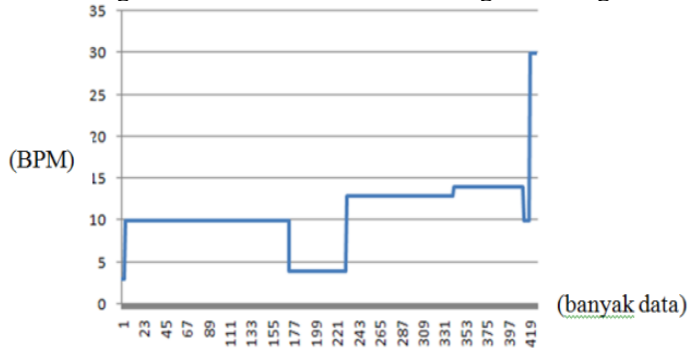

Gambar 20. Pengukuran Parameter Laju Napas Saat Pengiriman Radio

Dari data pengiriman tersebut terlihat bahwa hasil pengukuran parameter tidak stabil yaitu bisa naik dan turun secara drastis. Bahkan pengukuran yang dihasilkan dari parameter melebihi batas maksimal. Pada detak jantung batas maksimal jumlah detak per menit atau jumlah BPM tidak mungkin melebihi 200 BPM. Namun saat pengukuran parameter yang bersamaan dengan pengiriman radio terukur hingga 238 BPM. Pada laju napas batas maksimal jumlah napas per menit atau jumlah BPM tidak mungkin melebihi 20 BPM dalam keadaan normal. Namun saat pengukuran parameter yang bersamaan dengan pengiriman radio terukur hingga $30 \mathrm{BPM}$. Hasil pengukuran parameter detak jantung dan laju napas yang tidak stabil bisa dipengaruhi oleh faktor lain seperti tegangan input yang tidak stabil. Saat radio telemetry diaktifkan maka radio akan menyerap arus listrik lebih besar dari komponen lain untuk membangkitkan sinyal radio.

\section{G. Pengujian Fuzzy}

Setelah pengujian kedua sensor telah selesai dan didapatkan data yang diinginkan maka selanjutnya yaitu pengujian fuzzy. Dimana pada pengujian fuzzy ini dilakukan untuk mengetahui nilai data output yang apakah sudah sesuai atau belum. Data yang akan diperoleh yaitu nilai output dari kondisi tubuh apakah boleh lanjut atau berhenti melakukan olahraga.

Prosedur pengujiannya yaitu pertama menyambungkan alat yang telah dibuat ke sumber tegangan DC sebesar $9 \mathrm{~V}$, kemudian memasang sensor detak jantung pada jari dan sensor laju napas pada hidung. Setelah semua telah siap maka data bisa diamati dan dianalisa hasilnya pada LCD atau perangkat penerima radio. Berikut pada tabel 14 data hasil pengujian alat yang telah dilakukan.

Tabel 14 Data Pengujian Fuzzy

\begin{tabular}{|c|c|c|c|c|c|}
\hline No & $\begin{array}{l}\text { Laju } \\
\text { Napas }\end{array}$ & $\begin{array}{l}\text { Detak } \\
\text { Jantung }\end{array}$ & $\begin{array}{l}\text { Output } \\
\text { Fuzzy }\end{array}$ & $\begin{array}{l}\text { Rule } \\
\text { Base }\end{array}$ & Hasil \\
\hline 1 & 14 & 78 & Lanjut & Lanjut & S \\
\hline 2 & 17 & 92 & Lanjut & Lanjut & S \\
\hline 3 & 17 & 101 & Lanjut & Lanjut & S \\
\hline 4 & 20 & 115 & Berhenti & Berhenti & S \\
\hline 5 & 23 & 125 & Berhenti & Berhenti & S \\
\hline
\end{tabular}

Pada pengujian fuzzy ini nilai output fuzzy dan rule base telah sesuai. Saat laju napas bernilai 14 yaitu kondisi lambat dan detak jantung bernilai 78 kondisi normal sehingga rule base berupa kondisi lanjut dan output fuzzy berupa kondisi lanjut sehingga hasilnya sesuai. Saat laju napas bernilai 17 yaitu kondisi normal dan detak jantung bernilai 92 kondisi normal sehingga rule base berupa kondisi lanjut dan output fuzzy berupa kondisi lanjut sehingga hasilnya sesuai. Saat laju napas bernilai 17 yaitu kondisi normal dan detak jantung bernilai 101 kondisi normal sehingga rule base berupa kondisi lanjut dan output fuzzy berupa kondisi lanjut sehingga hasilnya sesuai. Saat laju napas bernilai 20 yaitu kondisi normal dan detak jantung bernilai 115 kondisi aktivitas ringan sehingga rule base berupa kondisi lanjut dan output fuzzy berupa kondisi lanjut sehingga hasilnya sesuai. Saat laju napas bernilai 23 yaitu kondisi cepat dan detak jantung bernilai 125 kondisi aktivitas ringan sehingga rule base berupa kondisi berhenti dan output fuzzy berupa kondisi berhenti sehingga hasilnya sesuai.

Hasil keputusan dari fuzzy akan ditunjukkan melalui hasil rule viewer dari desain yang telah dibuat. Yaitu input pertama (input1) merupakan hasil visualisasi dari himpunan detak jantung, input ke dua (input2) merupakan hasil visualisasi dari himpunan laju napas, dan output 1 merupakan hasil visualisasi dari himpunan output fuzzy berupa nilai dari kondisi lanjut dan berhenti. Berikut ke lima hasil pembuktian fuzzy pada sistem menggunakan software Matlab 2013.

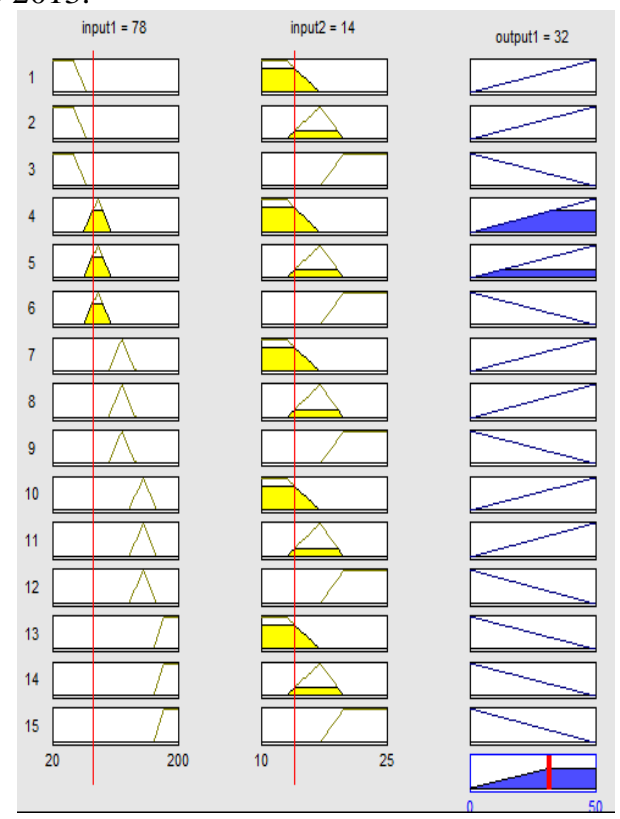


Gambar 21. Rule Viewer Data Pengujian 1 input1 $=92$
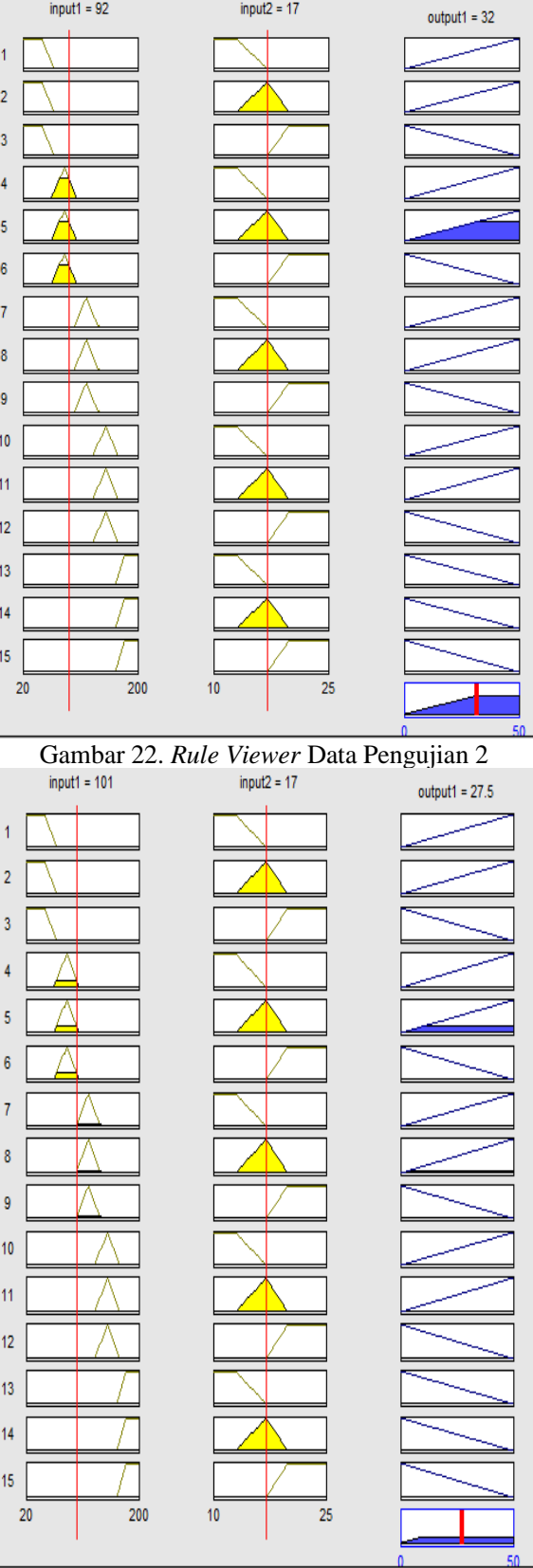

Gambar 23.Rule Viewer Data Pengujian 3 input1 $=115$

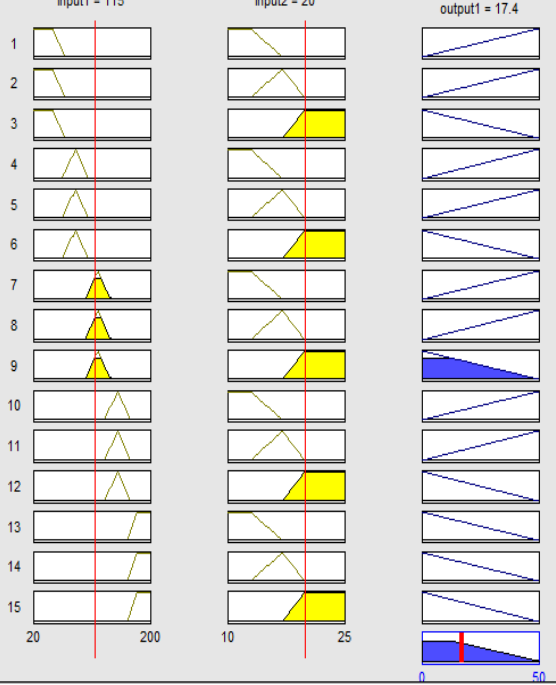

Gambar 24. Rule Viewer Data Pengujian 4

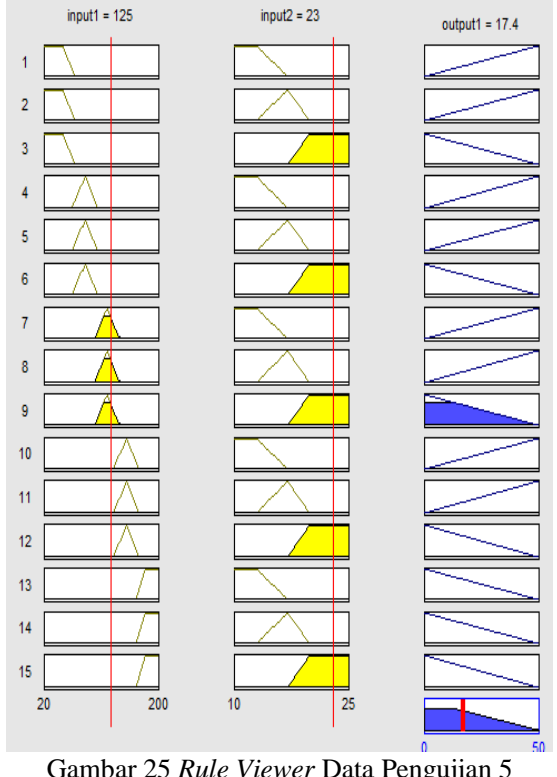

Seperti tampak pada gambar 21 sampai 25 dari ke lima hasil pengujian maka dapat dibuktikan bahwa alat yang dibuat telah sesuai dengan desain dari himpunan fuzzy (fuzzifikasi) dan sesuai dengan rule yang diinginkan. Selain pembuktian hasil perhitungan output fuzzy menggunakan Matlab, dapat pula dihitung secara manual.

H. Sistem Inferensi Fuzzy

Pengujian pertama :

a. Fuzzifikasi

1. Detak jantung $=78 \mathrm{BPM}$

$$
\begin{aligned}
\mu \text { Pelan } & =0 \\
\mu \text { Normal } & =\frac{78-65}{20}=\frac{13}{20}=0,65 \\
\mu \text { Ringan } & =0 \\
\mu \text { Berat } & =0 \\
\mu \text { Anaerob } & =0 \\
\text { 2. Laju napas }= & 14 \text { BPM } \\
\mu \text { Lambat } & =\frac{17-14}{4}=\frac{3}{4}=0,75 \\
\mu \text { Normal } & =\frac{14-13}{4}=\frac{1}{4}=0,25 \\
\mu \text { Cepat } & =0
\end{aligned}
$$

b. Operasi Logika Fuzzy

$\mu$ NormalnLambat $\mu$ Lambat(14)

$$
\begin{aligned}
& =\min (\mu \operatorname{Normal}(78)) ; \\
& =\min (0,65 ; 0,75) \\
& =0,65 \\
& =\min (\mu \operatorname{Normal}(78)) ; \\
& =\min (0,65 ; 0,25) \\
& =0,25
\end{aligned}
$$$$
\begin{array}{ll}
\mu \text { NormalnNormal } & =\min (\mu \operatorname{Normal}(78)) \\
\mu \text { Normal }(14) & =\min (0,65 ; 0,25)
\end{array}
$$

\begin{tabular}{|c|c|c|c|c|c|}
\hline $\begin{array}{c}\text { Detak } \\
\text { Jantung } \\
\begin{array}{c}\text { Laju } \\
\text { Napas }\end{array}\end{array}$ & Pelan & Normal & Ringan & Berat & Anaerob \\
\hline Lambat & 0 & 0,65 & 0 & 0 & 0 \\
\hline Normal & 0 & 0,25 & 0 & 0 & 0 \\
\hline Cepat & 0 & 0 & 0 & 0 & 0 \\
\hline
\end{tabular}

\section{c. Defuzzifikasi (Center of Area)}

Output $=\frac{\text { momen }}{\text { luas area }}$ 


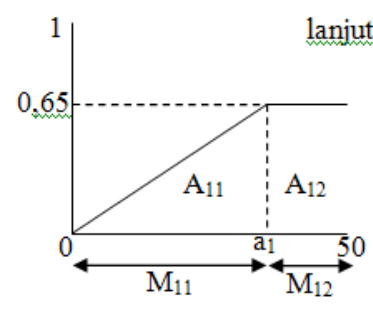

$0,65=\frac{a_{1}-0}{50} \rightarrow a_{1}=32,5$

Menghitung momen (M) :

$$
\begin{gathered}
\begin{aligned}
\mathrm{M}_{11}=\int_{0}^{32,5}\left(\frac{\mathrm{z}-0}{50}\right) \mathrm{zdz}=\int_{0}^{32,5}\left(0,02 \mathrm{z}^{2}-0 \mathrm{z}\right) \mathrm{dz} \\
=0,0067 \mathrm{z}^{3}-\left.0 \mathrm{z}^{2}\right|_{0} ^{32,5} \\
=229,9984375
\end{aligned} \\
\begin{aligned}
\mathrm{M}_{12}=\int_{32,5}^{50}(0,65) \mathrm{z} \mathrm{dz}= & 0,\left.325 \mathrm{z}^{2}\right|_{32,5} ^{50} \\
= & 469,21875
\end{aligned} \\
\mathrm{M}_{1}=\mathrm{M}_{11}+\mathrm{M}_{12}=229,9984375+469,21875 \\
=699,2171875
\end{gathered}
$$

Menghitung luas area (A) :

$$
\begin{aligned}
& A_{11}=\left(\frac{0,65 \times 32,5}{2}\right)=10,5625 \\
& A_{12}=(50-32,5) \times 0,65=11,375 \\
& A_{1}=A_{11}+A_{12}=10,5625+11,375=21,9375
\end{aligned}
$$

Menghitung titik pusat :

Output $_{1}=\frac{\mathrm{M}_{1}}{\mathrm{~A}_{1}}=\frac{699,2171875}{21,9375}=31,87$

Jadi kondisi yang dihasilkan dari perhitungan sebesar 31,87 merupakan kondisi lanjut.

Pengujian ke dua :

a. Fuzzifikasi

1. Detak jantung (92 BPM)

$$
\begin{aligned}
& \mu \text { Pelan } \quad=0 \\
& \mu \text { Normal }=\frac{105-92}{20}=\frac{13}{20}=0,65 \\
& \mu \text { Ringan }=0 \\
& \mu \text { Berat } \quad=0 \\
& \mu \text { Anaerob }=0 \\
& \mu \text { Lambat }=0 \\
& \mu \text { Normal }=1 \\
& \mu \text { Cepat }=0 \\
& \mu \text { NormalnNormal } \quad=\min (\mu \operatorname{Normal}(92)) \text {; } \\
& \mu \operatorname{Normal}(17) \quad=\min (0,65 ; 1) \\
& =0,65
\end{aligned}
$$

Tabel 16 Inferensi Pengujian 2

\begin{tabular}{|c|c|c|c|c|c|}
\hline $\begin{array}{c}\text { Detak } \\
\text { Jantung } \\
\text { Laju } \\
\text { Napas }\end{array}$ & Pelan & Normal & Ringan & $\begin{array}{c}\text { Ber } \\
\text { at }\end{array}$ & $\begin{array}{c}\text { Anaer } \\
\text { ob }\end{array}$ \\
\hline Lambat & 0 & 0 & 0 & 0 & 0 \\
\hline Normal & 0 & 0,65 & 0 & 0 & 0 \\
\hline Cepat & 0 & 0 & 0 & 0 & 0 \\
\hline
\end{tabular}

c. Defuzzifikasi (Center of Area) Output $=\frac{\text { momen }}{\text { luas area }}$

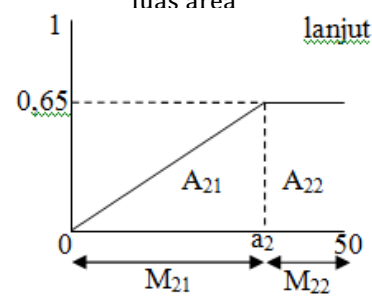

$0,65=\frac{\mathrm{a}_{2}-0}{50} \rightarrow \mathrm{a}_{2}=32,5$

Menghitung momen (M) :

$$
\begin{aligned}
& \mathrm{M}_{21}=\int_{0}^{32,5}\left(\frac{\mathrm{z}-0}{50}\right) \mathrm{zdz}=\int_{0}^{32,5}\left(0,02 \mathrm{z}^{2}-0 \mathrm{z}\right) \mathrm{dz} \\
&=0,0067 \mathrm{z}^{3}-\left.0 \mathrm{z}^{2}\right|_{0} ^{32,5} \\
&=229,9984375 \\
& \mathrm{M}_{22}=\int_{32,5}^{50}(0,65) \mathrm{z} \mathrm{dz}=0,\left.325 \mathrm{z}^{2}\right|_{32,5} ^{50} \\
&=469,21875 \\
& \mathrm{M}_{2}=\mathrm{M}_{21}+\mathrm{M}_{22}=229,9984375+469,21875 \\
&=699,2171875
\end{aligned}
$$

Menghitung luas area (A) :

$\mathrm{A}_{21}=\left(\frac{0,65 \times 32,5}{2}\right)=10,5625$

$A_{22}=(50-32,5) \times 0,65=11,375$

$A_{2}=A_{21}+A_{22}=10,5625+11,375=21,9375$

Menghitung titik pusat:

Output $_{2}=\frac{\mathrm{M}_{2}}{\mathrm{~A}_{2}}=\frac{699,2171875}{21,9375}=31,87$

Jadi kondisi yang dihasilkan dari perhitungan sebesar 31,87 merupakan kondisi lanjut.

Pengujian ke tiga :

a. Fuzzifikasi

1. Detak jantung (101 BPM)

$$
\begin{array}{ll}
\mu \text { Pelan } & =0 \\
\mu \text { Normal } & =\frac{105-101}{20}=\frac{4}{20}=0,2 \\
\mu \text { Ringan } & =\frac{101-100}{20}=\frac{1}{20}=0,005 \\
\mu \text { Berat } & =0 \\
\mu \text { Anaerob } & =0
\end{array}
$$

2. Laju napas (17 BPM)

$$
\begin{array}{ll}
\mu \text { Lambat } & =0 \\
\mu \text { Normal } & =1 \\
\mu \text { Cepat } & =0
\end{array}
$$

b. Operasi Logika Fuzzy

$\mu$ NormalnNormal $\mu \operatorname{Normal}(17)$

$\mu$ RingannNormal $\mu \operatorname{Normal}(17)$

$$
\begin{aligned}
& =\min (\mu \operatorname{Normal}(101)) ; \\
& =\min (0,2 ; 1) \\
& =0,2 \\
& =\min (\mu \operatorname{Ringan}(101)) ; \\
& =\min (0,005 ; 1) \\
& =0,005
\end{aligned}
$$

Tabel 17 Inferensi Pengujian 3

\begin{tabular}{|c|c|c|c|c|c|}
$\begin{array}{l}\text { Detak } \\
\text { Jantung } \\
\text { Laju } \\
\text { Napas }\end{array}$ & Pelan & Normal & Ringan & Berat & Anaerob \\
\hline Lambat & 0 & 0 & 0 & 0 & 0 \\
\hline Normal & 0 & 0,2 & 0,005 & 0 & 0 \\
\hline Cepat & 0 & 0 & 0 & 0 & 0 \\
\hline
\end{tabular}


c. Defuzzifikasi (Center of Area)

Output $=\frac{\text { momen }}{\text { luas area }}$

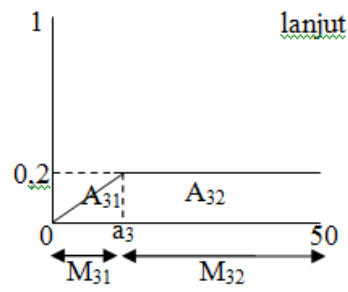

$0,2=\frac{\mathrm{a}_{3}-0}{50} \rightarrow \mathrm{a}_{3}=10$

Menghitung momen $(\mathrm{M})$ :

$$
\begin{aligned}
\mathrm{M}_{31}=\int_{0}^{10}\left(\frac{\mathrm{z}-0}{50}\right) \mathrm{zdz} & =\int_{0}^{10}\left(0,02 \mathrm{z}^{2}-0 \mathrm{z}\right) \mathrm{dz} \\
& =0,0067 \mathrm{z}^{3}-\left.0 \mathrm{z}^{2}\right|_{0} ^{10} \\
& =6,7 \\
\mathrm{M}_{32}=\int_{10}^{50}(0,2) \mathrm{z} \mathrm{dz} & =0,\left.1 \mathrm{z}^{2}\right|_{10} ^{50} \\
& =240 \\
\mathrm{M}_{3}=\mathrm{M}_{31}+\mathrm{M}_{32}=6,7+240 & =246,7
\end{aligned}
$$

Menghitung luas area (A) :

$\mathrm{A}_{31}=\left(\frac{0,2 \times 10}{2}\right)=1$

$\mathrm{A}_{32}=(50-10) \times 0,2=8$

$\mathrm{A}_{3}=\mathrm{A}_{11}+\mathrm{A}_{12}=1+8=9$

Menghitung titik pusat :

Output $_{3}=\frac{\mathrm{M}_{3}}{\mathrm{~A}_{3}}=\frac{246,7}{9}=27,41$

Jadi kondisi yang dihasilkan dari perhitungan sebesar 27,41 merupakan kondisi lanjut.

Pengujian ke empat :

a. Fuzzifikasi

1. Detak jantung (115 BPM)

$$
\begin{array}{ll}
\mu \text { Pelan } & =0 \\
\mu \text { Normal } & =0 \\
\mu \text { Ringan } & =\frac{115-100}{20}=\frac{15}{20}=0,75 \\
\mu \text { Berat } & =0 \\
\mu \text { Anaerob } & =0
\end{array}
$$

2. Laju napas (20 BPM)

$$
\begin{array}{ll}
\mu \text { Lambat } & =0 \\
\mu \text { Normal } & =0 \\
\mu \text { Cepat } & =1
\end{array}
$$

b. Operasi Logika Fuzzy

$\mu$ Ringan $\cap$ Cepat $=\min (\mu \operatorname{Ringan}(115))$;

$\mu$ Cepat $(20) \quad=\min (0,75 ; 1)$

$$
=0,75
$$

Tabel 18 Inferensi Pengujian 4

\begin{tabular}{|c|c|c|c|c|c|}
\hline $\begin{array}{c}\text { Detak } \\
\text { Jantung } \\
\text { Laju } \\
\text { Napas }\end{array}$ & Pelan & Normal & Ringan & Berat & $\begin{array}{c}\text { Anae } \\
\text { rob }\end{array}$ \\
\hline Lambat & 0 & 0 & 0 & 0 & 0 \\
\hline Normal & 0 & 0 & 0 & 0 & 0 \\
\hline Cepat & 0 & 0 & 0,75 & 0 & 0 \\
\hline
\end{tabular}

c. Defuzzifikasi (Center of Area)

Output $=\frac{\text { momen }}{\text { luas area }}$

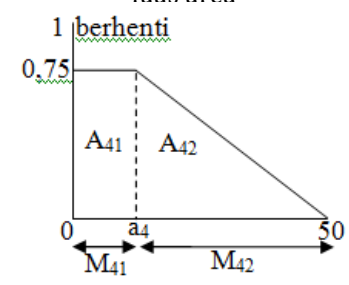

$0,75=\frac{50-\mathrm{a}_{4}}{50} \rightarrow \mathrm{a}_{4}=12,5$

Menghitung momen (M) :

$$
\begin{aligned}
\mathrm{M}_{41}=\int_{0}^{12,5}(0,75) \mathrm{z} \mathrm{dz} & =0,\left.375 \mathrm{z}^{2}\right|_{0} ^{12,5} \\
& =58,59375 \\
\mathrm{M}_{42}=\int_{12,5}^{50}\left(\frac{50-\mathrm{z}}{50}\right) \mathrm{z} \mathrm{dz} & =\int_{12,5}^{50}\left(\mathrm{z}-0,02 \mathrm{z}^{2}\right) \mathrm{dz} \\
& =0,5 \mathrm{z}^{2}-0,\left.0067 \mathrm{z}^{3}\right|_{12,5} ^{50} \\
& =347,4609375
\end{aligned}
$$

\begin{tabular}{|c|c|c|c|c|c|}
\hline $\begin{array}{c}\text { Jantung } \\
\text { Lajo } \\
\text { Napas }\end{array}$ & Pelan & Normal & Ringan & Berat & Anaerob \\
\hline Lambat & 0 & 0 & 0 & 0 & 0 \\
\hline Normal & 0 & 0 & 0 & 0 & 0 \\
\hline Cepat & 0 & 0 & 0,75 & 0 & 0 \\
\hline
\end{tabular}

$M_{4}=M_{41}+M_{42}=58,59375+347,4609375$

$$
=406,0546875
$$

Menghitung luas area (A) :

$$
\begin{aligned}
& \mathrm{A}_{41}=(0,75 \times 12,5) \quad=9,375 \\
& \mathrm{~A}_{42}=\left(\frac{50-12,5}{2}\right) \times 0,75 \quad=14,0625 \\
& \mathrm{~A}_{4}=\mathrm{A}_{41}+\mathrm{A}_{42}=9,375+14,0625=23,4375
\end{aligned}
$$

Menghitung titik pusat :

Output $_{4}=\frac{\mathrm{M}_{4}}{\mathrm{~A}_{4}}=\frac{406,0546875}{23,4375}=17,32$

Jadi kondisi yang dihasilkan dari perhitungan sebesar 17,32 merupakan kondisi berhenti.

Pengujian ke lima :

a. Fuzzifikasi

1. Detak jantung (125 BPM)

$$
\begin{aligned}
\mu \text { Pelan } & =0 \\
\mu \text { Normal } & =0 \\
\mu \text { Ringan } & =\frac{140-125}{20}=\frac{15}{20}=0,75 \\
\mu \text { Berat } & =0 \\
\mu \text { Anaerob } & =0 \\
\text { 2. Laju napas }(23 & \text { BPM }) \\
\mu \text { Lambat } & =0 \\
\mu \text { Normal } & =0 \\
\mu \text { Cepat } & =1
\end{aligned}
$$

b. Operasi Logika Fuzzy

$\mu$ Ringan $\cap$ Cepat $=\min (\mu \operatorname{Ringan}(125)$;

$\mu$ Cepat $(23) \quad=\min (0,75 ; 1)$

$$
=0,75
$$


c. Defuzzifikasi (Center of Area)

Output $=\frac{\text { momen }}{\text { luas area }}$

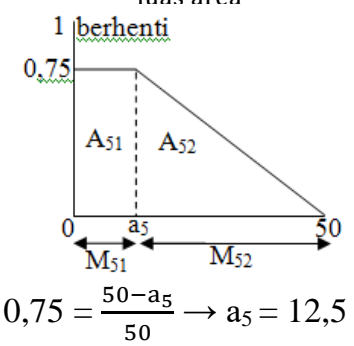

Menghitung momen (M) :

$$
\begin{aligned}
\mathrm{M}_{51}=\int_{0}^{12,5}(0,75) \mathrm{z} \mathrm{dz} & =0,\left.375 \mathrm{z}^{2}\right|_{0} ^{12,5} \\
& =58,59375 \\
\mathrm{M}_{52}=\int_{12,5}^{50}\left(\frac{50-\mathrm{z}}{50}\right) \mathrm{zdz} & =\int_{12,5}^{50}\left(\mathrm{z}-0,02 \mathrm{z}^{2}\right) \mathrm{dz} \\
& =0,5 \mathrm{z}^{2}-0,\left.0067 \mathrm{z}^{3}\right|_{12,5} ^{50} \\
& =347,4609375
\end{aligned}
$$

$\mathrm{M}_{5}=\mathrm{M}_{51}+\mathrm{M}_{52}=58,59375+347,4609375$

$$
=406,0546875
$$

Menghitung luas area (A) :

$$
\begin{array}{ll}
\mathrm{A}_{51}=(0,75 \times 12,5) & =9,375 \\
\mathrm{~A}_{52}=\left(\frac{50-12,5}{2}\right) \times 0,75 & =14,0625
\end{array}
$$$$
A_{5}=A_{51}+A_{52}=9,375+14,0625=23,4375
$$

Menghitung titik pusat :

Output $_{4}=\frac{\mathrm{M}_{5}}{\mathrm{~A}_{5}}=\frac{406,0546875}{23,4375}=17,32$

Jadi kondisi yang dihasilkan dari perhitungan sebesar 17,32 merupakan kondisi berhenti.

Dari hasil perhitungan pada Tabel 4.8 terlihat bahwa hasil perhitungan manual dan hasil perhitungan Matlab tidak jauh berbeda. Dengan nilai error pada percobaan pertama sebesar $0,4 \%$. Pada percobaan ke dua sebesar $0,4 \%$. Pada percobaan ke tiga sebesar $0,32 \%$. Pada percobaan ke empat sebesar 0,46\%. Pada percobaan ke lima sebesar 0,46\%. Nilai selisih pada error masih sangat kecil sehingga data dikatakan sesuai. Hasil perhitungan juga sesuai dengan rule yang telah dibuat.

Tabel 20 Hasil Perhitungan Output

\begin{tabular}{|c|c|c|c|}
\hline $\begin{array}{c}\text { Data } \\
\text { ke }\end{array}$ & $\begin{array}{c}\text { Perhitungan } \\
\text { Manual }\end{array}$ & $\begin{array}{c}\text { Perhitungan } \\
\text { Matlab }\end{array}$ & $\begin{array}{c}\text { Error } \\
(\%)\end{array}$ \\
\hline 1 & 31,87 & 32 & 0,4 \\
\hline 2 & 31,87 & 32 & 0,4 \\
\hline 3 & 27,41 & 27,5 & 0,32 \\
\hline 4 & 17,32 & 17,4 & 0,46 \\
\hline 5 & 17,32 & 17,4 & 0,46 \\
\hline
\end{tabular}

Setelah proses pengujian alat telah selesai maka data yang telah terukur akan tersimpan pada memori SD card secara langsung setelah proses pengukuran selesai. Data yang tersimpan pada SD card dengan judul 'data.txt' yang berupa file notepad. Format penyimpanannya yaitu pertama memasukan hasil pengukuran laju napas lalu di beri spasi satu tab lalu selanjutnya hasil pengukuran detak jantung, dan lalu di beri spasi satu tab lalu selanjutnya hasil perhitungan output fuzzy. Kemudian jika ada pengujian berkali-kali maka data akan terus menerus menyimpan seperti format tersebut berurutan. Jika memori SD card error atau tidak dapat menyimpan maka pada layar LCD akan muncul peringatan berupa "SD card error".

\section{KESIMPULAN}

Berdasarkan pengujian yang telah dilakukan didapatkan beberapa kesimpulan bahwa pengujian sensor nilai error terbesar yaitu 5,95\% pada detak jantung dan $8 \%$ pada laju napas. Sedangkan nilai error terkecil yaitu 1,06\% pada detak jantung dan $0 \%$ pada laju napas. Jarak maksimum pengiriman data menggunakan radio tanpa penghalang sejauh 140 meter dan dengan penghalang sejauh 96 meter. Hasil pengujian fuzzy telah sesuai dengan rule base yang telah dibuat dan telah dibuktikan dengan perhitungan manual dan matlab.

\section{REFERENS}

[1] Palar, Chrisly M dkk. 2015. Manfaat Latihan Olahraga Aerobik Terhadap Kebugaran Fisik Manusia. Jurnal e-Biomedik (eBm), Volume 3, Nomor 1, Januari-April 2015

[2] Giriwijoyo, Prof. H.Y.S Santosa dan Dr. Didik Z.S, M.Pd. 2012. Ilmu Kesehatan Olahraga. Bandung: PT. Remaja Rosdakarya.

[3] Ganong, William F. 2008. Buku Ajar Fisiologi Kedokteran. Jakarta: Buku Kedokteran EGC.

[4] Meivita, Dewi Nurhaji. 2016. Rancang Bangun Alat Ukur Kondisi Kesehatan Pada Pendaki Gunung Berbasis Fuzzy Logic. Yogyakarta, Seminar Nasional Aplikasi Teknologi Informasi (SNATI), ISSN:1907-5022

[5] Patil, Harshavardhan B dan Prof.V.M.Umale. 2015. Arduino Based Wireless Biomedical Parameter Monitoring System Using Zigbee. International Journal of Engineering Trends and Technology (IJETT) ISSN: 2231-5381 Volume 28 Number 7.

[6] Kale, Aniket V. dkk. 2015. GSM Based Heart Rate and Temperature Monitoring System. International Journal of Engineering Research \& Technology (IJERT) ISSN: 2278-0181 Vol. 4 Issue 04.

[7] Kuswandi, Son. 2007. Kendali Cerdas. Yogyakarta: CV. Andi Offset

[8] Mallick, Bandana dan Ajit Kumar Patro. 2016. Heart Rate Monitoring System Using Finger Tip Through Arduino And Processing Software. International Journal of Science, Engineering and Technology Research (IJSETR), ISSN: 2278 - 7798 Volume 5, Issue 1, January 2016

[9] Hadiyoso, Sugondo dkk. 2015. Implementasi Regulator Oksigen Otomatis berdasarkan Tingkat Pernapasan Menggunakan Logika Fuzzy. Teknik Elektro Itenas Jurnal ELKOMIKA ISSN: 2338-8323 No. 1 Vol. 3 Januari - Juni 2015 